\title{
PENGARUH MINAT BELAJAR DAN KECERDASAN INTELEKTUAL MAHASISWA TERHADAP PRESTASI BELAJAR PENDIDIKAN PANCASILA DAN KEWARGANEGARAAN
}

\author{
Mawardi Nurullah \\ Fakultas Ekonomi, Universitas Pamulang \\ nurullahmawardi@gmail.com \\ Naskah diterima: 1 Maret 2018, review I: 2 Maret 2018, revisi I: 6 Maret 2018, \\ review II: 7 Maret 2018, revisi II: 10 Maret 2018, disetujui: 16 Maret 2018.
}

\begin{abstract}
The purpose of this study is to determine the interests and intellectual intelligence together with the achievement of Pancasila and Citizenship Education learning on semester 1 students of Pamulang University. That interest in learning is something that can awaken or encourage a person to be diligent in learning to achieve the desired goals by trying to know, follow, understand, concentrate, to achieve high achievement. In the learning activities of each learner will be influenced by his intellectual intelligence personally. Through the intellectual intelligence of the students are trying to set goals that must be achieved. The results of this study found that Achievement learning Citizenship Education on average is 66,825 and there are still $40 \%$ who have values below the average so categorized quite good or moderate. Improvement of learning achievement of Pancasila and Citizenship Education (PPKn) can improve student's interest in learning better. Second, the results showed the dominant influence of intellectual intelligence is higher than the interest in learning. Therefore, the intellectual intelligence of students is always honed, so often given the task of homework both individually and in groups. Third, further research is needed which includes variables other than interest in learning and intellectual intelligence as a more complete predictor of Pancasila and Citizenship Education achievement. Moreover, there are still 50.1\% sources of variation that cannot be explained by interest in learning and intellectual acumen.
\end{abstract}

Keywords: learning interest, students' intellectual, learning achievement, citizenship education

\footnotetext{
Jurnal Pendidikan Kewarganegaraan

Journal of Civics and Education Studies

The journal is published by Department of Civic Education

Faculty of Teacher Training and Education

Universitas Pamulang - Indonesia
}

Copyright (C) 2018 | ISSN: 2302-0865 


\section{PENDAHULUAN}

Upaya peningkatan kualitas pendidikan di Indonesia dilakukan sebagai langkah utama yang diambil oleh Pemerintah adalah dengan penetapan Undang-Undang RI No. 20 Tahun 2003 tentang sistem Pendidikan Nasional. Dalam pelaksanaannya, kampus sebagai salah satu institusi/lembaga pendidikan/pelatihan mempunyai tujuan (tujuan institusional) yakni menghasilkan lulusan dengan kemampuan (pengetahuan, ketrampilan, dan sikap) yang dibutuhkan masyarakat. Pendidikan Pancasila dan Kewarganegaraan (PPKn) mengarahkan pada pembentukan moral yang diharapkan diwujudkan dalam perilaku sehari-hari.

Melalui Pendidikan Pancasila dan Kewarganegaraan ini para Mahasiswa diharapkan mampu mengembangkan potensinya baik sebagai pribadi, anggota masyarakat, bangsa dan negara maupun sebagai anggota masyarakat dunia. Disamping itu, para Mahasiswa juga dibekali pengetahuan dan kemampuan dasar berkenaan dengan hubungan antara warga negara dengan negara serta pendidikan pendahuluan bela negara. PPKn sebagai mata pelajaran yang diarahkan terhadap upaya peningkatan, pemahaman, penghayatan, dan pengamalan nilai-nilai moral yang berakar pada budaya bangsa Indonesia yang diharapkan dapat diwujudkan dalam bentuk perilaku sehari-hari Mahasiswa baik sebagai individu, sebagai anggota masyarakat, dan warga negara. Perilaku yang dimaksud dalam PPKn adalah perilaku yang mencerminkan iman dan taqwa kepada Tuhan Yang Maha Esa.

Maka sebab itu pendidikan sangatlah penting dalam kehidupan manusia dan tidak terbatas pada umur. Suatu negara yang mutu pendidikannya rendah akan mengakibatkan terhambatnya kemajuan suatu negara. Dalam UU No. 20 tahun 2003 tentang sistem Pendidikan Nasional, tercantum pengertian pendidikan: Pendidikan adalah usaha dasar dan terencana untuk mewujudkan suasana belajar dan proses pembelajaran agar peserta didik secara aktif mengembangkan potensi dirinya sehingga memiliki kekuatan spiritual keagamaan, pengendalian diri, kepribadian, kecerdasan, akhlak mulia, serta keterampilan yang diperlukan oleh dirinya, masyarakat, bangsa dan negara.

Pendidikan berguna untuk mewujudkan sumber daya manusia yang berkualitas sehingga negara menjadi maju dan tidak menjadi negara yang terbelakang dari pada negara lain dalam berbagai aspek baik ekonomi, politik, sosial dan sebagainya. Maka dari itu pemerintah perlu menyediakan anggaran khusus untuk pendidikan sesuai dalam UUD 45 pasal 31 ayat 4 yang berbunyi: "Negara memprioritaskan anggaran pendidikan sekurang-kurangnya dua puluh persen dari anggaran pendapatan dan belanja negara serta dari anggaran pendapatan dan belanja daerah untuk memenuhi kebutuhan penyelenggaraan pendidikan nasional".

Pemerintah perlu merealisasikan seperti yang tertulis dalam Undang- 
Undang dengan mempersiapkan anggaran khusus untuk pendidikan yang berjumlah $20 \%$ dari anggaran pendapatan dan belanja negara untuk memenuhi kebutuhan penyelenggaraan pendidikan nasional. Hal ini untuk menanggulangi rendahnya mutu pendidikan pada setiap jenjang dan satuan pendidikan, yang merupakan salah satu dari permasalahan pendidikan yang sedang dihadapi oleh bangsa Indonesia sekarang ini.

Berbagai usaha telah dilakukan untuk meningkatkan mutu pendidikan nasional, baik dengan pengembangan kurikulum, peningkatan kompetensi pendidik, pengadaan buku dan alat pelajaran, sarana pendidikan serta perbaikan manajemen kampus. Dengan berbagai usaha ini ternyata belum juga menunjukkan peningkatan yang signifikan. Peran serta warga kampus dalam penyelenggaraan pendidikan selama ini sangat kurang, partisipasi pendidik dalam pengambilan keputusan sering terabaikan. Padahal terjadi atau tidak terjadinya perubahan di kampus sangat tergantung pada para pendidiknya. Oleh karena itu, pendidik dan masyarakat kampus harus memiliki tanggung jawab dalam melaksanakan program-program kampus.

Pendidik perlu memahami bahwa apapun yang dilakukan di ruang kelas mempunyai pengaruh, baik positif maupun negatif terhadap motivasi Mahasiswa, cara pendidik menyajikan pelajaran, bagaimana kegiatan belajar dikelola di kelas, cara pendidik berinteraksi dengan Mahasiswa kiranya dilakukan oleh pendidik secara terencana dengan perbaikan dan perubahan baik dalam metode, manajemen kampus yang terus dilakukan diharapkan dapat meningkatkan perbaikan mutu pendidikan di Indonesia.

Menurut Kartono (2000), "mendidik dan mengajar merupakan perbuatan terpuji dan berdedikasi tinggi untuk membawa anak manusia pada tingkat manusiawi dan taraf peradaban, khususnya pada jaman modern dengan segala kompleksitasnya". Tanpa pendidikan anak tidak akan dapat mencapai martabat kemanusiaan, tidak bisa menjadi pribadi utuh, juga tidak bisa menjadi insan sosial dan abdi Tuhan Yang Maha Esa yang saleh.

Berdasarkan latar belakang masalah tersebut di atas kemudian diidentifikasikan beberapa masalah sebagai berikut: 1) Minat belajar Mahasiswa masalah utama dalam pembelajaran adalah Mahasiswa tidak memiliki pola belajar yang sistematis; 2) Kecerdasan intelektual Mahasiswa masih rendah; dan 3) Adakah pengaruh minat belajar dan kecerdasan intelektual Mahasiswa secara bersama-sama terhadap Prestasi Belajar Pendidikan Pancasila dan Kewarganegaraan (PPKn)?

Dalam suatu penelitian perlu adanya rumusan masalah untuk menghindari permasalahan lain yang sebenarnya tidak perlu dibahas atau tidak ada korelasinya. Rumusan masalah dalam penelitian ini adalah:

1. Apakah terdapat pengaruh minat dan kecerdasan intelektual secara bersama-sama terhadap Prestasi 
Belajar Pendidikan Pancasila dan Kewarganegaraan (PPKn) Mahasiswa Semester 1 di Universitas Pamulang?

2. Apakah terdapat pengaruh minat terhadap Prestasi Belajar Pendidikan Kewarganegaraan Pancasila (PPKn) Mahasiswa Semester 1 Universitas Pamulang?

3. Apakah terdapat pengaruh kecerdasan intelektual terhadap Prestasi Belajar Pendidikan Pancasila dan Kewarganegaraan (PPKn) Mahasiswa Semester 1 Universitas Pamulang?

Berdasarkan masalah penelitian yang telah dirumuskan tujuan yang ingin dicapai dalam penelitian ini adalah:

1. Untuk mengetahui pengaruh minat dan kecerdasan intelektual secara bersama-sama terhadap Prestasi Belajar Pendidikan Pancasila dan Kewarganegaraan (PPKn) Mahasiswa Semester 1 Universitas Pamulang.

2. Untuk mengetahui pengaruh minat terhadap Prestasi Belajar Pendidikan Pancasila dan Kewarganegaraan (PPKn) Mahasiswa Semester 1 Universitas Pamulang.

3. Untuk mengetahui pengaruh kecerdasan intelektual terhadap Prestasi Belajar Pendidikan Pancasila dan Kewarganegaraan (PPKn) Mahasiswa Semester 1 Universitas Pamulang.

Menurut Poerwadarminta (2002: 768) bahwa prestasi belajar Pendidikan Kewarganegaraan adalah hasil yang dicapai seorang Mahasiswa setelah mengikuti pelajaran PPKn di kampus sehingga terjadi perubahan dalam dirinya dengan melihat hasil penguasaan, pengetahuan, dan ketrampilan yang dikembangkan oleh pendidik setelah mengikuti assesment atau penilaian dan evaluasi. Penilaian dan evaluasi digunakan untuk mengukur prestasi belajar PPKn Mahasiswa yang merupakan tujuan dari pembelajaran.

Dari berbagai pendapat tentang prestasi belajar adalah perubahan yang terjadi pada diri Mahasiswa sebagai akibat dari kegiatan belajar yang dinyatakan dalam bentuk skor atau kegiatan evaluasi (test) yang telah dilakukan. Bertujuan untuk mengukur kemampuan dan kemajuan Mahasiswa dari keseluruhan mata pelajaran atau salah satu mata pelajaran di kampus.

Minat merupakan aspek psikologis yang akan mempengaruhi belajar. Adapun minat yang dapat menunjang belajar adalah minat terhadap materi bahan belajar dan terhadap pendidik yang mengajarnya. Peranan minat dalam belajar adalah sebagai motivating force yaitu sebagai kekuatan yang akan mendorong Mahasiswa untuk belajar sehingga dapat meraih prestasi belajar yang tinggi. Mahasiswa yang berminat (sikapnya senang) terhadap mata pelajaran akan tampak terdorong terus untuk tekun belajar.

Menurut psikologi, minat merupakan pola reaksi individu terhadap sesuatu stimukus atau lingkungan. Dapat pula diartikan minat adalah suatu kecenderungan untuk selalu memperhatikan dan mengingat sesuatu terus menerus. Minat belajar ekonomi 
meruoakan kondisi psikologis dalam diri manusia yang dapat membangkitkan gairah kreativitas untuk mencapai cita-cita dalam bidang sejarah. Mahasiswa yang memiliki minat ia akan cenderung berusaha untuk lebih aktif, berusaha memahami konsep dan prinsip objek yang dipelajari.

Minat belajar merupakan sesuaru yang dapat membangkitkan atau nedorong seseorang untuk menajdi giat belajar dalam mencapai cita-cita yang ia inginkan berusaha untuk mengetahui suatu pelajaran dengan cara mengetahui, mengikuti, memahami pelajaranm memusatkan perhatian, belajar lebih giat, dan akhirnya mencapai prestasi yang diinginkan. Minat belajar akan melahirkan perhatian, memudahkan terciptanya konsentrasi, mencegah gangguan perhatian dari luar, memperkuat melekatnya bahan pelajaran dalam ingatan, memperkecil kebosanan studi dalam diri sendiri (Gie, 1994: 28).

Dari pengertian di atas disimpilkan bahwa minat belajar adalah sesuatu yang dapt membangkitkan atau mendorong seseorang untuk menjadi giat belajar dalam mencapai cita-cita yang diinginkan dengan berusaha untuk mengetahui, mengikuti, memahami, memusatkan perhatian, untuk mencapai prestasi yang tinggi.

Keberhasilan Mahasiswa dalam mengikuti proses pembelajaran dipengaruhi oleh faktor internal yang berkembang dalam dirinya, faktor tersebut adalah kecerdasan atau kecerdasn intelektual yang diperoleh dari faktor keuturunan. Faktor ketrampilan yaitu kemampuan menggunakan atau mengoperasikan sesuatu yang didapat dari pembelajaran serta faktor bakat dan minat. Keberadaan faktor ekternal secara langsung berpengaruh terhadap perilaku belajar. Faktor eksternal yang dimaksud adalah kondisi lingkungan belajar di kampus maupun lingkungan rumah tangga. Kedua faktor tersebut secara lansung mampu mempengaruhi perilaku dan perbuatan seseorang. Dalam hal ini perlu ada strategi yang afektif dari pendidik agar proses pembelajaran mampu membangun meningkatkan minat dan prestasi belajar Mahasiswa.

Lebih lanjut Suryabrata (200: 224) menyatakan bahwa hakekat kecerdasan intelektual dapat dibedakan dalam tiga kelompok yang diantaranya adalah; 1) Kecenderungan menetapkan tujuan; 2) Kemampuan menyesuaikan potensi dalam mencapai tujuan; dan 3) Kemampuan mengkritik diri sendiri.

Dalam kegiatan belajar masingmasing peserta didik akan dipengaruhi oleh kecerdasan intelektual pribadinya. Melalui kecerdasan intelektual tersebut Mahasiswa berusaha menetapkan tujuan yang harus dicapai. Penetapkan tujuan akan ia susun dengan kempuannya, jika Mahasiswa merasa bahwa tujuan yang diharapkan sesuai dengan kemampuannya maka dalam dirinya akan terbentuk rasa percaya diri dan keyakinan akan dapat memperoleh hasil optimal. Selanjutnya Mahasiswa juga memiliki kemampuan mengkritik diri sendiri, kritik yang disampaikan dapat berperan sebagai feed 
back yang memberi masukan baru dan keinginan memperbaiki kelemahan sehingga menghasilkan pola kerja yang lebih optimal.

Kemampuan sedemikian mampu membangun harapan dalam diri Mahasiswa untuk mampu meraih prestasi belajar yang lebih baik dari yang telah diraih sebelumnya atau diraih oleh Mahasiswa lainnya. Kemampuan berkompetisi sedemikian mampu membangun harapan dalam diri Mahasiswa untuk mampu meriah prestasi belajar yang lebih baik dari yang telah diraih sebelumnya atau diraih oleh Mahasiswa lainnya. Kemampuan berkompetisi dengan sesama peserta didik akan tebangun secara baik jika Mahasiswa mampu membangun rasa percaya diri yang didukung oleh kecerdasan intelektual tinggi. Menurut Freeman dikutip dari Barrow (1997: 228) menyatakan bahwa kecerdasan intelektual dibedakan dalam tiga kemampuan yang diantaranya; 1) Kemampuan beradaptasi; 2) Kemampuan untuk belajar; dan 3) Kemampuan berpikir abstrak.

Hubungan antar variabel dalam penelitian ini dapat dinyatakan dalam sebuah kerangka pemikiran yang dapat ditunjukkan oleh gambar sebagai berikut:



Gambar 1. Kerangka Pemikiran
Penelitian bertujuan untuk mengetahui pengaruh minat dan kecerdasan intelektual secara sendirisendiri maupun secara bersama-sama, terhadap Prestasi Belajar Pendidikan Pancasila dan Kewarganegaraan (PPKn) pada Mahasiswa Semester 1 Universitas Pamulang.

\section{METODE PENELITIAN}

Metode yang digunakan dalam penelitian ini adalah penelitian korelasi dengan teknik survei. Variabel penelitian ini terdiri dari variabel terikat (dependent variabel), yaitu Prestasi Belajar Pendidikan Pancasila dan Kewarganegaraan (PPKn) (Y) dan dua variabel bebas (independent variable), yaitu minat $\left(\mathrm{X}_{1}\right)$, dan kecerdasan intelektual $\left(\mathrm{X}_{2}\right)$.

Prosedur penelitian sesuai dengan konstelasi antar variabel dalam penelitian ini adalah sebagai berikut :

1. Variabel Bebas $\left(\mathrm{X}_{1}\right)$, yaitu minat, metode penelitian yang digunakan dengan teknik menyebarkan instrumen yang berbentuk angket (kuesioner) yang berjumlah 30 butir pertanyaan pada Mahasiswa Semester 1 yang bukan menjadi obyek penelitian berjumlah 30 Mahasiswa dan mengumpulkan kembali angket (kuesioner) yang telah dijawab. Penyebaran ini mempunyai tujuan untuk mengetahui butir pertanyaan instrumen apakah valid dan reliabel, kemudian dibuang untuk tidak digunakan dalam butir pertanyaan instrumen yang akan disebarkan kepada Mahasiswa Semester 1 yang 
menjadi obyek penelitian (sampel yang berjumlah 40 Mahasiswa) yang sama dengan pemilihan data hasil tes psikologi pada variabel bebas $\left(\mathrm{X}_{2}\right)$, yaitu kecerdasan intelektual.

2. Variabel Bebas $\left(\mathrm{X}_{1}\right)$, yaitu kecerdasan ontelektual, metode penelitian yang digunakan dengan teknik mengumpulkan dokumen hasil tes psikologi yaitu tes kecerdasan Mahasiswa ketika Mahasiswa baru masuk di kelas X (sepuluh). Kemudian memilih data Mahasiswa yang menjadi obyek penelitian (sampel penelitian) sejumlah 40 Mahasiswa.

3. Variabel Terikat (Y), yaitu Prestasi Belajar Pendidikan Kewarganegaraan (PPKn), metode penelitian yang digunakan dengan teknik dokumentasi, yaitu mengambil nilai hasil ulangan matakuliah Pendidikan Pancasila Kewarganegaraan (PPKn) pada semester I tahun pelajaran 2017/2018.

Semua informasi data yang diperlukan sudah tesedia, kemudian data diolah sesuai dengan hipotesis peneltian (regresi) yang selanjutnya menjadi acauan dalam menentukan kesimpulan penelitian.

Populasi adalah keseluruhan dari objek penelitian dan populasi juga merupakan wilayah generalisasi berupa subjek atau objek yang menjadi kuantitatif atau karakteristik tertentu yang ditetapkan oleh peneliti untuk dipelajari dan kemudian diambil kesimpulan (Sugiyono dalam Ridwan, 2004: 54). Nawawi dalam Ridwan (2004: 54) menyebutkan bahwa "populasi adalah totalitas dari semua nilai yang mungkin, baik hasil menghitung atau pengukuran kuantitatif pada karakteristik tert entu mengenai sekumpulan obyek yang lengkap".

Populasi dalam penelitian ini adalah seluruh seluruh Mahasiswa Semester 1 Universitas Pamulang. Tahun pelajaran 2016/2017 yang terdiri 10 kelas. Sedangkan populasi terjangkau dalam penelitian ini adalah Mahasiswa Semester 1 yang berjumlah 521 Mahasiswa.

Sugiyono (2005: 56) mengatakan bahwa: "sampel adalah sebagian dari jumlah dan karakteristik yang dimiliki populasi". Pengertian sampel menurut Sudjana (2005: 161), menyatakan "sampel adalah sebagian yang diambil dari populasi dengan menggunakan cara-cara tertentu".

Teknik pengambilan sampel dilakukan dengan menggunakan metode simple random sampling yaitu pengambilan sampel anggota populasi dilakukan secara acak tanpa memperhatikan strata yang ada dalam populasi itu. Jumlah sampel ditetapkan sebanyak 40 Mahasiswa, yang diambi dari 20 Mahasiswa Semester 1 Kelas A, dan 20 Mahasiswa Kelas B yang diambil dengan teknik random sampling.

Prestasi Belajar Pendidikan Pancasila dan Kewarganegaraan (PPKn) adalah penilaian tingkat hasil belajar atas penguasaan atau keterampilan yang dicapai oleh peserta didik setelah melakukan proses belajar mengajar matakuliah Pendidikan Pancasila dan Kewarganegaraan (PPKn) dalam upaya 
mencapai tujuan pembelajaran yang telah ditetapkan dan biasanya dinyatakan dalam bentuk angka, simbol, huruf maupun kalimat yang dapat mencerminkan hasil yang sudah dicapai pada periode tertentu.

Prestasi Belajar Pendidikan Pancasila dan Kewarganegaraan (PPKn) adalah Skor penilaian tingkat hasil belajar atas penguasaan atau keterampilan yang dicapai oleh Mahasiswa Semester 1 setelah melakukan proses belajar mengajar matakuliah Pendidikan Kewarganegaraan (PPKn) dalam upaya mencapai tujuan pembelajaran yang telah ditetapkan dan biasanya dinyatakan dalam bentuk angka, simbol, huruf maupun kalimat yang dapat mencerminkan hasil yang sudah dicapai pada semester I tahun pelajaran 2017/2018.

\section{HASIL DAN PEMBAHASAN}

Terdapat pengaruh yang signifikan antara minat dan kecerdasan intelektual secara bersama-sama terhadap prestasi belajar Pendidikan Pancasila dan Kewarganegaraan (PPKn) mahasiswa semester 1 Universitas Pamulang. Hal tersebut dibuktikan dengan nilai Fhitung $(18,417)>$ Ftabel $(3,252)$, nilai Sig $=0,000<0,05$. Variabel bebas minat dan kecerdasan intelektual secara bersamasama menyumbang sebesar 49,9\% terhadap variasi prestasi belajar Pendidikan Pancasila dan Kewarganegaraan (PPKn).

Terdapat pengaruh yang signifikan minat terhadap prestasi belajar Pendidikan Pancasila dan Kewarganegaraan (PPKn) Mahasiswa
Semester 1 Universitas Pamulang. Hal tersebut dibuktikan dengan nilai thitung $(3,070)>$ ttabel $(1,69)$, nilai Sig $=0,004$ $<0,05$.

Terdapat pengaruh yang signifikan kecerdasan intelektual terhadap Prestasi Belajar Pendidikan Pancasila dan Kewarganegaraan (PPKn) Mahasiswa Semester 1 Universitas Pamulang. Hal tersebut dibuktikan dengan nilai thitung $(4,216)>$ ttabel $(1,69)$, nilai Sig $=0,000$ $<0,05$.

\section{KESIMPULAN}

Prestasi belajar Pendidikan Pancasila dan Kewarganegaraan (PPKn) dalam penelitian ini perlu ditingkatkan lagi. Hasil penelitian ini menemukan bahwa Prestasi belajar Pendidikan Pancasila Kewarganegaraan (PPKn) secara rata-rata adalah 66,825 dan masih ada $40 \%$ yang memiliki nilai di bawah rata-rata sehingga dikategorikan cukup baik atau sedang. Peningkatan Prestasi belajar Pendidikan Pancasila dan Kewarganegaraan (PPKn) tersebut bisa dengan meningkatkan minat belajar mahasiswa lebih baik lagi.

Hasil penelitian menunjukkan dominasi pengaruh kecerdasan intelektual lebih tinggi dibandingkan dengan minat belajar. Oleh karena itu agar kecerdasan intelektual mahasiswa selalu terasah, agar sering diberikan tugas pekerjaan rumah baik secara individu maupun secara kelompok.

Perlu penelitian lebih lanjut yang memasukkan variabel selain minat belajar dan kecerdasan intelektual sebagai prediktor yang lebih lengkap bagi prestasi 
belajar Pendidikan Pancasila dan Kewarganegaraan (PPKn). Dan masih ada $50,1 \%$ sumber variasi yang tidak bisa dijelaskan oleh minat belajar dan kecerdasan intelektual.

\section{REFERENSI}

Adiwangsa, S. (2007). Kecerdasan Anak. Bandung: Mutiara Press.

Ahmadi, A. \& Supriono, W. (1991). Psikologi Belajar. Jakarta: Rineka Cipta.

Aji, M. P. (1998). Meningkatkan Prestasi Belajar Anak. Yogyakarta: Gema Ilmu Press.

Azwar. (2004). Intelegensi Anak. Jakarta: Balai Pustaka.

Darmansyah, D. (2009). Tugas Perkembangan Individu. Jakarta: Persada Press.

Departemen Pendidikan dan Kebudayaan, Dirjen Dikdasmen. (1998). Konsep Dasar Pendidikan Terbuka. Jakarta: Depdikbud.

Departemen Pendidikan Nasional. (2004). Kurikulum Kampus Menengah Atas. Jakarta: Balai Pustaka.

Direktorat Jenderal Pendidikan Tinggi. (1998). Mengukur Prestasi dan Kemampuan. Jakarta: Dirjen Dikti.

Djaali \& Muljono, P. (2004). Pengukuran dalam Bidang Pendidikan. Jakarta: PSS - Universitas Negeri Jakarta

Fahrudin, F. (2008). Kecerdasan dan Prestasi. Jakarta: Persada Ilmu Press.

Haryadi, R. J. (2009). Kecerdasan Masa Perkembangan. Jakarta: Cipta Nusa.

Hibabudin, M. (1990). Pengantar Psikologi Pendidikan. Jakarta: Bina Ilmu.
Hardiman, A. (1990). Kesatuan Kecerdasan Intelektual dengan Aktivitas. Jakarta: Nirwana Mulia.

Fauzia, M. (2000). Sukses Meraih Prestasi Melalui Pendidikan. Jakarta: Vista Jaya Press.

Firdaus, A. (1989). Tingkat Aspirasi Pendidikan dan Harapan. Yogyakarta: Gajahmada Press.

Fudyatanta. (2007). Intelegensi Umum. Medan: Puspa Ilmu.

Kamus Besar Bahasa Indonesia. (1995). Istilah Ilmiah dan Ilmu Pengetahuan. Jakarta: Balai Pustaka.

Kasim, R. (2005). Intelegensi dan Kemampuan Berfikir. Bandung: Insani.

Kresnaji. (1996). Cita - cita dan Pendidikan. Bandung: Remaja Rosdakarya.

Malik, M. (2007). Kecerdasan Intelektual Anak. Yogyakarta: Karunia Ilmu

Ngalim, P. (2003). Ilmu Pendidikan Teoritis dan Praktis. Bandung: PT. Remaja Rosda Karya

Prayitno, E. (1999). Motivasi dalam Belajar. Jakarta: Dirjen Dikti Depdikbud.

Rahman, A. (1999). Psikologi Kognitif. Yogyakarta: Pustaka Karya.

Riyanto, Y. (2001). Metodologi Penelitian Pendidikan. Surabaya: Penerbit SIC.

Rusdi. (1997). Cita - cita dan Prestasi Belajar. Jakarta: Purnama Press.

Rusyan, T. (1994). Sistematika Belajar. Semarang: Obor Mas.

Safari. (2006). Analisis Butir Soal. Jakarta : CIV. Purnama.

Sagala, S. (2005). Konsep dan Makna Pembelajaran. Bandung: Alfabeta.

Sardiman, A. M. (2001). Interaksi dan Motivasi Belajar. Jakarta: Rajawali Press. 
Setyorini, S. (2007). Mengembangkan Kemampuan Anak. Bandung: Bintang Cemerlang.

Slameto. (1995). Belajar dan Faktor-faktor yang Mempengaruhinya. Jakarta: Bina Aksara

Soemanto. (2006). Perkembangan Intelegensi Anak dan Remaja. Bandung: Bintang Timur Press

Suarta, I. N. (1998). Pendidikan dan Prestasi. Semarang: Nirwana.

Sudjana, N. (1999). Penilaian Hasil Proses Belajar Mengajar. Bandung: Remaja Rosda Karya.

Sugiono. (2003). Statistik untuk Penelitian. Bandung: CV. Alfabeta

Sujana, C. (2004). Metode Statistika. Bandung: Transito.
Suryabrata, S. (1998.) Psikologi Pendidikan: Materi Pendidikan Program Bimbingan dan Konseling di Perpendidikan Tinggi. Yogyakarta: Depdikbud.

Sutopo, H. (1998). Kecerdasan dan Hasil Belajar. Semarang: Cakrawala

Sutrisno, H. (2000). Metodologi Research Jilid I. Yogyakarta: Andi Offset.

Suwardoyo. (1998). Cara Cerdas Berprestasi Belajar. Surabaya: Pustaka Ilmu.

Utami, M. (1992). Mengembangkan Bakat dan Kreatifitas Anak Kampus, Petunjuk Bagi Para Pendidik dan Orang Tua. Jakarta: Rasindo.

Widagdo, S. (2008). Psikologi Kognitif. Yogyakarta: Surya Press.

Winarno, S. (1996). Pengertian Interaksi Belajar Mengajar. Bandung: Transito. 